\title{
What should interventional cardiologists do for patients with prediabetes?
}

\author{
(क) $(3)$ Nicolas Danchin ${ }^{1,2,3 *}, \mathrm{MD}$ \\ 1. Hôpital Européen Georges Pompidou, Paris, France; 2. Université Paris Descartes, Paris, France; \\ 3. INSERM U-970, Paris, France
}

Diabetes mellitus is a growing medical concern. Among patients with coronary artery disease and those with myocardial infarction, the reported prevalence of diabetes ranges between 20 and $40 \%$.

Those patients with recognised diabetes mellitus do not, however, constitute the totality of patients presenting with dysglycaemia. Whereas the increased cardiovascular risk specifically related to diabetes in coronary patients is well known and documented, less attention has been given to prediabetes and its interaction with cardiovascular outcomes.

In the current issue of EuroIntervention, Kok et al present an analysis of clinical outcomes in a cohort of nearly 3,000 patients after percutaneous coronary intervention (PCI) with implantation of biodegradable or non-degradable polymer drug-eluting stents (DES), according to their glycaemic status ${ }^{1}$.

Article, see page 1049

The first lesson is that $14 \%$ of the patients without previously known diabetes had prediabetes and an additional 7\% had overt diabetes; overall, dysglycaemic patients represented $37 \%$ of the total population of patients undergoing PCI. These figures reflect the magnitude of the problem of unknown dysglycaemia in patients with coronary artery disease. They are in line with our own findings in the patients with acute myocardial infarction (AMI) included in the FAST-MI programme in France ${ }^{2}$ : based on $\mathrm{HbA} 1 \mathrm{c}$ levels at admission, $20 \%$ of the patients without previously recognised diabetes had prediabetes, and $8 \%$ had diabetes (Figure 1). In the Korean AMI registry, 59.5\% of the patients without known diabetes undergoing primary PCI for STEMI had prediabetes $^{3}$. Likewise, impaired glucose tolerance based upon an oral glucose tolerance test two weeks after discharge in a Spanish population undergoing PCI (76\% for acute coronary syndromes) was found in $24.5 \%$, with an additional $16 \%$ having newly diagnosed diabetes ${ }^{4}$.

The second lesson is more encouraging: overall patient management was in line with current recommendations, and did not markedly differ according to diabetic status. In fact, patients with prediabetes received statins, newer $\mathrm{P} 2 \mathrm{Y}_{12}$ inhibitors, beta-blockers and ACE inhibitors or angiotensin receptor blockers at least as often as non-dysglycaemic patients. The corollary is that one can 


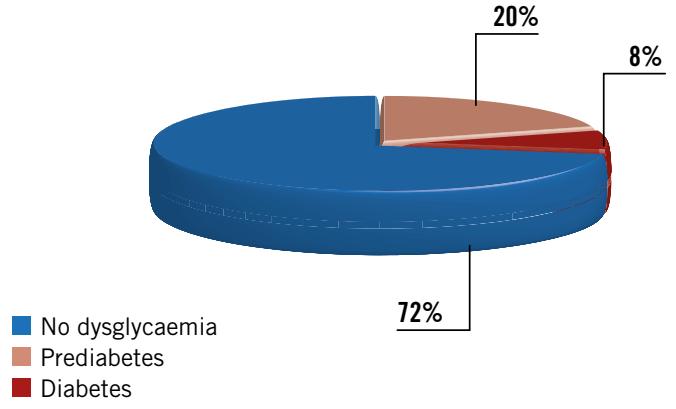

Figure 1. Prevalence of dysglycaemia and newly diagnosed diabetes based upon HbA1c values in the FAST-MI 2005-2015 registries.

hardly expect to improve the clinical outcomes of patients with prediabetes by improving prescription of cardiovascular medications at discharge.

The third finding is that clinical outcomes were much poorer in dysglycaemic patients, including in terms of one-year mortality, and were similar between patients with prediabetes and those with diabetes. These findings should be interpreted in the light of the potential limitations of the study: in particular, the diagnosis of prediabetes was based either on $\mathrm{HbA1c}$ values or on fasting plasma glucose (FPG) values. If the former probably reflect the patients' chronic glycaemic status, the latter can also reflect the extent of myocardial damage in patients presenting with AMI ( $>50 \%$ of the population), independently of their chronic glycaemic status. Judging by the low number of patients with severe left ventricular dysfunction, however, it seems unlikely that this confounding factor could have been more than a minor contributor to the worse outcomes observed in patients with dysglycaemia. In fact, in the French FAST-MI cohorts, and based only upon HbA1c values, the five-year mortality of prediabetic patients was close to that of diabetic patients (Figure 2). Recently, results from another contemporary cohort, in Korean patients treated with DES exclusively for stable coronary artery disease, showed increased

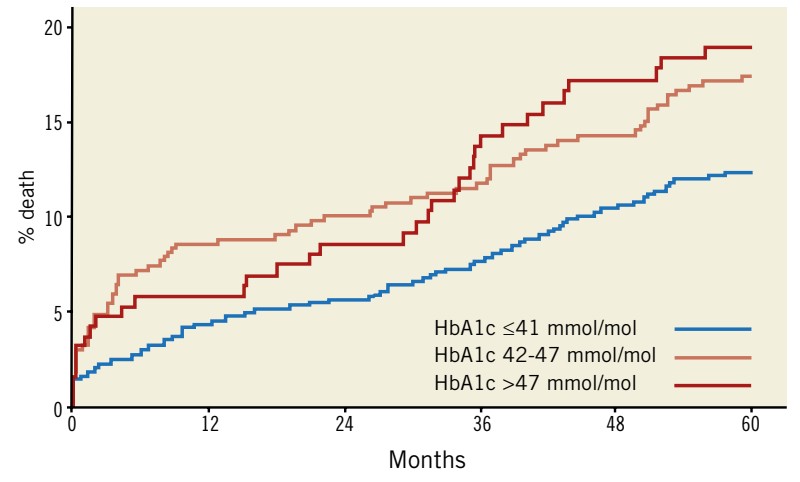

Figure 2. Five-year mortality in AMI patients without history of known diabetes, according to HbAlc levels at admission in the FAST-MI 2005 and 2010 registries. two-year mortality $(5.5 \%$ vs. $1.5 \%, \mathrm{p}=0.007)$ in patients with prediabetes, as well as a trend to higher rates of in-stent restenosis $(15.6 \% \text { vs. } 9.8 \%, \mathrm{p}=0.066)^{5}$.

Overall, if patients with prediabetes are indeed at increased long-term risk, with a risk similar to that of diabetic patients, what can we do to improve things? Optimisation of secondary prevention medications, as well as lifestyle modification is a prerequisite for improving outcomes. Newer hypoglycaemic medications (SGLT2 inhibitors and GLP1 agonists) reduce cardiovascular events in patients with recognised diabetes mellitus and coronary artery disease ${ }^{6-8}$. Whether these medications can also improve outcomes in dysglycaemic patients without overt diabetes is unknown and will require specific clinical trials. So far, the effects of medications such as insulin glargine or n-3 fatty acids in patients with prediabetes have been disappointing ${ }^{9,10}$.

However, beyond these measures, the best revascularisation options in these patients should be carefully analysed, as they are in diabetic patients. A recent meta-analysis based on individual data of more than 11,000 patients randomised to coronary artery bypass surgery or PCI with stents for left main or multivessel disease has shown that there was no difference in outcome between the two revascularisation options in non-diabetic patients, whereas in diabetic patients mortality was considerably less with coronary artery bypass surgery, with a $5 \%$ difference in all-cause mortality at five years between the two revascularisation techniques ${ }^{11}$. These results, together with observational data in multivessel disease patients with either stable ischaemic heart disease or acute coronary syndromes (excluding STEMI patients $\leq 72$ hours from admission) ${ }^{12}$, form the basis of the current European Society of Cardiology recommendation that coronary bypass surgery should be the preferred option in diabetic patients ${ }^{13}$. The present study, showing similar outcomes after stenting in patients with diabetes or prediabetes, therefore suggests that, at least in prediabetic patients with multivessel disease, coronary artery surgery might be the best revascularisation strategy when the operative risk is not considered too high. It might be time for interventional cardiologists and cardiac surgeons to envisage a contemporary comparative trial in the large population of patients presenting with prediabetes.

\section{Conflict of interest statement}

N. Danchin has received research grants from Amgen, AstraZeneca, Bayer, Boehringer-Ingelheim, Daiichi Sankyo, Eli Lilly, Merck, Pfizer, and Sanofi and fees for lectures or consulting from Amgen, AstraZeneca, Bayer, Bristol-Myers Squibb, Boehringer-Ingelheim, Daiichi Sankyo, Eli Lilly, MSD, Novo Nordisk, Pfizer, Sanofi, and Servier.

\section{References}

1. Kok MM, von Birgelen C, Sattar N, Zocca P, Löwik MM, Danse PW, Schotborgh CE, Scholte M, Hartmann M, Kant GD, Doelman C, Tjon Joe Gin M, Stoel MG, van Houwelingen G, Linssen GCM, IJzerman MJ, Doggen CJM, van der Heijden LC. Prediabetes and its impact on clincial outcome after coronary 
intervention in a broad patient population. EuroIntervention. 2018; 14:e1049-56.

2. Puymirat E, Simon T, Cayla G, Cottin Y, Elbaz M, Coste P, Lemesle G, Motreff P, Popovic B, Khalife K, Labèque JN, Perret T, Le Ray C, Orion L, Jouve B, Blanchard D, Peycher P, Silvain J, Steg PG, Goldstein P, Gueret P, Belle L, Aissaoui N, Ferrieres J, Schiele F, Danchin N; USIK, USIC 2000, and FAST-MI investigators. Acute Myocardial Infarction: Changes in Patient Characteristics, Management, and 6-Month Outcomes Over a Period of 20 Years in the FAST-MI Program (French Registry of Acute STElevation or Non-ST-Elevation Myocardial Infarction) 1995 to 2015. Circulation. 2017;136:1908-19.

3. Shin D, Ahn J, Cha KS, Park JS, Oh JH, Lee HW, Hong JY, Kim BW, Hong TJ; Korea Working Group on Myocardial Infarction Investigators. Impact of initial glycosylated hemoglobin level on cardiovascular outcomes in prediabetic patients with ST-segment elevation myocardial infarction undergoing primary percutaneous coronary intervention. Coron Artery Dis. 2016;27:40-6.

4. de la Hera JM, Delgado E, Hernandez E, Garcia-Ruiz JM, Vegas JM, Avanzas P, Lozano I, Barriales-Villa R, Hevia S, Martin JS, Alvarez F, Moris C. Prevalence and outcome of newly detected diabetes in patients who undergo percutaneous coronary intervention. Eur Heart J. 2009;30:2614-21.

5. Choi WG, Rha SW, Choi BG, Choi SY, Byun JK, Mashaly A, Park Y, Jang WY, Kim W, Choi JY, Park EJ, Na JO, Choi CU, Kim EJ, Park CG, Seo HS. The Impact of Prediabetes on Two-Year Clinical Outcomes in Patients Undergoing Elective Percutaneous Coronary Intervention. Yonsei Med J. 2018;59:489-94.

6. Zinman B, Wanner C, Lachin JM, Fitchett D, Bluhmki E, Hantel S, Mattheus M, Devins T, Johansen OE, Woerle HJ, Broedl UC, Inzucchi SE; EMPA-REG OUTCOME Investigators. Empagliflozin, Cardiovascular Outcomes, and Mortality in Type 2 Diabetes. N Engl J Med. 2015;373:2117-28.

7. Marso SP, Daniels GH, Brown-Frandsen K, Kristensen P, Mann JF, Nauck MA, Nissen SE, Pocock S, Poulter NR, Ravn LS, Steinberg WM, Stockner M, Zinman B, Bergenstal RM, Buse JB; LEADER Steering Committee; LEADER Trial Investigators. Lira- glutide and cardiovascular outcomes in type 2 diabetes. $N$ Engl $J$ Med. 2016;375:311-22.

8. Marso SP, Bain SC, Consoli A, Eliaschewitz FG, Jodar E, Leiter LA, Lingvay I, Rosenstock J, Seufert J, Warren ML, Woo V, Hansen O, Holst AG, Pettersson J, Vilsboll T; SUSTAIN-6 Investigators. Semaglutide and Cardiovascular Outcomes in Patients with Type 2 Diabetes. N Engl J Med. 2016;375:1834-44.

9. ORIGIN Trial Investigators, Bosch J, Gerstein HC, Dagenais GR, Diaz R, Dyal L, Jung H, Maggiono AP, Probstfield J, Ramachandran A, Riddle MC, Rydén LE, Yusuf S. N-3 fatty acids and cardiovascular outcomes in patients with dysglycemia. $N$ Engl J Med. 2012;367:309-18.

10. ORIGIN Trial Investigators, Gerstein HC, Bosch J, Dagenais GR, Diaz R, Jung H, Maggioni AP, Pogue J, Probstfield J, Ramachandran A, Riddle MC, Rydén LE, Yusuf S. Basal insulin and cardiovascular and other outcomes in dysglycemia. $N$ Engl $J$ Med. 2012;367:319-28.

11. Head SJ, Milojevic M, Daemen J, Ahn JM, Boersma E, Christiansen EH, Domanski MJ, Farkouh ME, Flather M, Fuster V, Hlatky MA, Holm NR, Hueb WA, Kamalesh M, Kim YH, Makikallio T, Mohr FW, Papageorgiou G, Park SJ, Rodriguez AE, Sabik JF 3rd, Stables RH, Stone GW, Serruys PW, Kappetein AP. Mortality after coronary artery bypass grafting versus percutaneous coronary intervention with stenting for coronary artery disease: a pooled analysis of individual patient data. Lancet. 2018;391:939-48.

12. Ramanathan K, Abel JG, Park JE, Fung A, Mathew V, Taylor CM, Mancini GBJ, Gao M, Ding L, Verma S, Humphries KH, Farkouh ME. Surgical Versus Percutaneous Coronary Revascularization in Patients With Diabetes and Acute Coronary Syndromes. J Am Coll Cardiol. 2017;70:2995-3006.

13. Neumann FJ, Sousa-Uva M, Ahlsson A, Alfonso F, Banning AP, Benedetto U, Byrne RA, Collet JP, Falk V, Head SJ, Jüni P, Kastrati A, Koller A, Kristensen SD, Niebauer J, Richter DJ, Seferovic PM, Sibbing D, Stefanini GG, Windecker S, Yadav R, Zembala MO; ESC Scientific Document Group. 2018 ESC/EACTS Guidelines on myocardial revascularization. Eur Heart J. 2018 Aug 25. [Epub ahead of print]. 